\title{
Correction to: Mathematics Teacher Education in the Andean Region and Paraguay
}

\section{Correction to:}

\author{
Y. Y. Baldin and Malaspina (eds.), Mathematics Teacher Education \\ in the Andean Region and Paraguay, \\ https://doi.org/10.1007/978-3-319-97544-3
}

The original version of the book was published in 2016 with exclusive rights reserved by the Publisher. As of December 2020 it has been changed to an open access publication: (c) The Editor(s) (if applicable) and The Author(s) 2016.

The copyright of the individual chapters has therefore changed to: () The Author(s) 2016 All chapters in the book are licensed under the terms of the Creative Commons Attribution-NonCommercial-NoDerivatives 4.0 International License.

Any third party material is under the same Creative Commons license as the book unless specified otherwise below.

The updated version of this book can be found at https://doi.org/10.1007/978-3-319-97544-3 